\title{
Feasibility of genetic testing for cancer risk assessment programme in Nigeria
}

\author{
Prisca O Adejumo ${ }^{1}$, Toyin I G Aniagwu ${ }^{2}$, Olutosin A Awolude ${ }^{3}$, Abiodun O Oni ${ }^{4}$, Olubunmi O Ajayi ${ }^{3}$, Omolara Fagbenle $^{5}$, \\ Dasola Ogungbade ${ }^{6}$, Makayla Kochheiser ${ }^{7,8}$, Temidayo Ogundiran ${ }^{4}$ and Olufunmilayo I Olopade ${ }^{7,8}$ \\ ${ }^{1}$ Department of Nursing, College of Medicine, University of Ibadan, Ibadan, 200284, Nigeria \\ ${ }^{2}$ School of Occupational Health Nursing, University College Hospital, Ibadan, 200212, Nigeria \\ ${ }^{3}$ Department of Obstetrics and Gynaecology, College of Medicine, University of Ibadan/University College Hospital, Ibadan, 200284, Nigeria \\ ${ }^{4}$ Department of Surgery, University College Hospital, Ibadan, 200212, Nigeria \\ ${ }^{5}$ Department of Radiation Oncology, University College Hospital, Ibadan, 200212, Nigeria \\ ${ }^{6}$ Department of Radiology, University College Hospital, Ibadan, 200212, Nigeria \\ ${ }^{7}$ Center for Clinical Cancer Genetics, University of Chicago, Chicago, IL, 60637, USA \\ ${ }^{8}$ Center for Global Health, University of Chicago, Chicago IL, 60637, USA
}

The abstract was presented in part at the Consortiums of Universities for Global Health Conference, Chicago, April 2019.

\section{Abstract}

Background: A high frequency of BRCA mutations has been established in Nigerian breast cancer (BC) patients. Recently, patients' and first-degree relatives' interest have been raised on cancer genetic risk assessment through our awareness activities in Nigeria. This led to the emergence of nurse-led cancer genetic counselling (CGC) and testing aimed at providing standard-of-care for individuals at increased risk of hereditary breast and ovarian cancers .

Methods: In June 2018, CGC and testing of patients with BC and ovarian cancer (OC) commenced in collaboration with Color Genomics Inc. for a 30-panel gene testing. Previously trained nurses in CGC at the University College Hospital, Ibadan offered genetic counselling (GC) to willing patients with $\mathrm{BC}$ and gynaecological cancer in four out-patient oncology clinics and departments for the pilot study. Consultation consisted of CGC, patient's history, pedigree and sample collection for genetic testing (GT).

Results: Forty-seven patients - 40 with $\mathrm{BC}$, five with $\mathrm{OC}$ and two with endometrial cancer received GC, and all chose to undergo GT. The average age at testing was $48.2 \pm$ 12.1 years. Eight women reported a known family cancer history and there were more perceived benefits than barriers to GT with the patients experiencing the desire for none of their relative to have cancer. Results revealed no mutations in 27 (57.4\%), 16 (4.0\%) variants of unknown significance and 4 (8.5\%) pathogenic mutations.

Conclusion: Personalised cancer care utilises GC and testing for cancer risk assessment towards prevention and early detection in high risk women. The study indicates the necessity of expanded cancer genetic services for integration into patient care and cancer prevention.

Keywords: breast cancer, ovarian cancer, genetic counselling, genetic testing, genetic risk assessment

Correspondence to: Toyin I G Aniagwu Email: taniagwu@yahoo.com

ecancer 2021, 15:1283

https://doi.org/10.3332/ecancer.2021.1283

Published: 07/09/2021

Received: 27/01/2021

Publication costs for this article were supported by ecancer (UK Charity number 1176307).

Copyright: ( $)$ the authors; licensee ecancermedicalscience. This is an Open Access article distributed under the terms of the Creative Commons Attribution License (http:// creativecommons.org/licenses/by/4.0), which permits unrestricted use, distribution, and reproduction in any medium, provided the original work is properly cited. 


\section{Introduction}

Hereditary cancer syndromes account for approximately 5\%-10\% of all cancers [1, 2] with breast cancer (BC) and ovarian cancer (OC) association with germline mutations established since the early 1990s [3]. Hereditary breast and ovarian cancer (HBOC) is a syndrome particularly affecting certain populations [4] like the African-American women [5] and African women [6, 7]. Studies in Nigeria, the most populous African country, have reported a high frequency of germline mutations, particularly of BRCA1/2 variant associated with $\mathrm{HBOC}$ risk, in the Nigerian women of up to $16 \%[8,9]$. The implication is that many Nigerian women have up to an $85 \%$ and $46 \%$ lifetime risk of BC and OCs, respectively. While BC is the leading cause of cancer death in women in Nigeria, OC incidence is increasing and remains the most fatal of all gynaecological cancers $[10,11]$ particularly due to late presentation of these cancer cases $[12,13]$ associated with absent effective methods for screening and early diagnosis.

Evaluation of the likelihood of a patient having one of these cancer predisposition syndromes enables physicians to provide individualised assessments of cancer risk, as well as the opportunity to provide tailored screening and prevention strategies such as surveillance, chemoprevention and prophylactic surgery that may reduce the morbidity and mortality associated with these syndromes [14]. This is especially so now that genetic risk assessment is rapidly becoming an expectation in oncology care $[15,16]$. A review of service models for provision of genetic healthcare [17] highlighted the effective use of multidisciplinary clinics and services to ensure that patients and families have access to this coordinated care. However as highly proposed and used, BC and OC prevention have not explored this novel opportunity in low- and middle-income countries like Nigeria [18]. There is low awareness of cancer genetics in Nigeria [18] and resources for risk assessment and communication have been lacking. This has led to a growing demand in knowledge for genetic testing (GT) services [19]. The establishment of a cancer risk assessment programme therefore will bridge the knowledge gap about cancer genetics between health professionals and patients [20]. Genetic counseling (GC) and subsequent testing for deleterious gene mutations impacts psychosocial assessment and support, derivation of personalised risks and the likelihood of identifying a mutation with genetic susceptibility testing [14]. This will increase family understanding of testing options and ensure that the most appropriate test is ordered, allowing for informed decision making, and ensuring that families are prepared for the outcomes of testing [21].

Enquiries are made by patients and their relatives on cancer genetic risk assessment through our recent awareness activities on cancer genetics in Nigeria. This led to the emergence of a nurse-led cancer genetic counselling (CGC) and testing. This study aimed to explore the feasibility of GT for risk assessment programme in Nigeria in making CGC and testing standard-of-care for individuals at increased risk of HBOCs by introducing the services to cancer care at the University College Hospital, Ibadan.

\section{Methods}

We conducted a pilot study testing the feasibility of integrating systematic cancer risk assessment and GC as a standard and routine component of oncology management at the University College Hospital (UCH) , Ibadan, Nigeria between July and August 2018. Nurses who received a 1 week abridged intensive training in CGC at the UCH, Ibadan in 2014-2015 offered GC to willing patients with BC, OC and endometrial cancer, but without prior genetic counselling and testing (GCT) in four out-patient oncology clinics and departments of the hospital. The nurses' training was based on the Cancer Genetics and Risk Management training which the lead nurse and the coordinating nurse had received from the University of lowa, The University of Chicago and the City of Hope, United States of America from 2013 to 2016. Counselling and interview session discussions included educating about genetics of hereditary breast and gynaecological cancers, benefits and risks of GC; documentation of personal and family history with pedigree drawing; determination of cancer mutation risk, GT methods and meaning of results. Consenting patients were, subsequently, tested with 30 cancer susceptibility gene panel in the Color ${ }^{\circledR}$ Genomics kit which include BAP1, MITF, CDK4, CDKN2A, ATM, CDH1, NBN, CHEK2, PTEN, BRCA1, BRCA2, PALB2, BARD1, BRIP1, TP53, STK11, MLH1, MSH2, EPCAM, MSH6, PMS2, RAD51C, RAD51D, APC, BMPR1A, SMAD4, GREM1, MUTYH, POLD1, POLE using targeted sequencing panel. Sequencing was done on an Illumina NextSeq 500/550 instrument for 150 bp paired-end sequencing. The genetic variants were reviewed, discussed and classified as likely pathogenic, or pathogenic and variants of uncertain significance, according to the American College of Medical Genetics and Genomics 2015 guidelines. 
After testing, patients completed a semi-standardised questionnaire assessing their socio-demographic information, family cancer history and perceived benefits and barriers to GT. Ethical approval for the study was obtained from the University of Ibadan (UI)/UCH Ethics Committee with the number $\mathrm{UI} / \mathrm{EC} / 18 / 0251$. Institutional support was obtained, based on the awareness previously raised on CGC.

\section{Results}

Forty-seven women with cancers $(B C=40(85.1 \%), O C=5(10.0 \%)$ and endometrial $=2(4.3 \%))$ who consented to participate were recruited from the oncology clinics and departments of the selected hospital. The women received GC and subsequently, had GT. The mean age at the time of testing was 48.2 ( \pm 12.1 years; Range: $28-70$ ) years. Family history of cancer was reported by eight (17.0\%) of the women (Table 1 ).

Perceived personal risk of cancer recurrence and the lifetime risk of their relatives showed that $42.8 \%$ believed that they cannot have cancer again while $17.2 \%$ agreed to a risk of $50 \%$ and above. A considerable proportion of participants had a view that their children (24.0\%), siblings (25.5\%) and parents (13.5\%) have above 50\% risk of developing cancer (Table 2).

Table 1. Participants' sociodemographic characteristics $N=47$.

\begin{tabular}{|c|c|c|}
\hline Characteristics & Frequency & $\%$ \\
\hline $\begin{array}{l}\text { Type of cancer } \\
\text { Breast } \\
\text { Ovarian } \\
\text { Endometrial }\end{array}$ & $\begin{array}{c}40 \\
5 \\
2\end{array}$ & $\begin{array}{c}85.1 \\
10.6 \\
4.3\end{array}$ \\
\hline $\begin{array}{l}\text { Gender } \\
\text { Female }\end{array}$ & 47 & 100.0 \\
\hline $\begin{array}{l}\text { Marital status } \\
\text { Single } \\
\text { Married } \\
\text { Separated/divorced } \\
\text { Widowed }\end{array}$ & $\begin{array}{c}1 \\
36 \\
3 \\
7\end{array}$ & $\begin{array}{c}2.1 \\
76.5 \\
6.4 \\
14.9\end{array}$ \\
\hline $\begin{array}{l}\text { Religion } \\
\text { Christianity } \\
\text { Islamic }\end{array}$ & $\begin{array}{l}35 \\
12\end{array}$ & $\begin{array}{l}74.5 \\
25.5\end{array}$ \\
\hline $\begin{array}{l}\text { Ethnicity } \\
\text { Yoruba } \\
\text { Ibo } \\
\text { Others }\end{array}$ & $\begin{array}{c}33 \\
9 \\
5\end{array}$ & $\begin{array}{l}70.2 \\
19.1 \\
10.6\end{array}$ \\
\hline $\begin{array}{l}\text { Highest educational qualification } \\
\text { Elementary } \\
\text { Secondary } \\
\text { Diploma / National Certificate of Education } \\
\text { B.Sc. } \\
\text { M.Sc. } \\
\text { Ph.D. }\end{array}$ & $\begin{array}{c}7 \\
7 \\
13(27.7) \\
17(36.2) \\
2(4.3) \\
1(2.1)\end{array}$ & $\begin{array}{c}14.9 \\
14.9 \\
27.7 \\
36.2 \\
4.3 \\
2.1\end{array}$ \\
\hline $\begin{array}{l}\text { Any family had cancer } \\
\text { Yes } \\
\text { No }\end{array}$ & $\begin{array}{c}8 \\
39\end{array}$ & $\begin{array}{l}17.0 \\
83.0\end{array}$ \\
\hline \multicolumn{3}{|c|}{ Mean age: $48.2 \pm 12.1$ years; Range: $28-70$ years } \\
\hline Mean income: N51,542 \pm N46,007; $(\$ 136 \pm$ & ge: N2,00 & t to $-\$ 474)$ \\
\hline
\end{tabular}


Table 2. Participants' perceived risk of personal and relative cancer risk.

\begin{tabular}{|c|c|c|}
\hline $\begin{array}{l}\text { Perceived lifetime risk of relatives developing cancer } \\
\text { ( } 0 \text { is the lowest perceived risk, } 10 \text { highest perceived risk) }\end{array}$ & Frequency & $\%$ \\
\hline $\begin{array}{l}\text { Risk of developing cancer again } n=35 \\
0 \\
1 \\
2 \\
3 \\
5 \\
7 \\
8 \\
10\end{array}$ & $\begin{array}{c}15 \\
1 \\
8 \\
5 \\
2 \\
1 \\
2 \\
1\end{array}$ & $\begin{array}{c}42.8 \\
2.9 \\
22.8 \\
14.3 \\
5.7 \\
2.9 \\
5.7 \\
2.9\end{array}$ \\
\hline $\begin{array}{l}\text { Lifetime risk of children } n=25 \\
0 \\
1 \\
2 \\
3 \\
4 \\
5 \\
6 \\
8\end{array}$ & $\begin{array}{c}16 \\
5 \\
5 \\
2 \\
3 \\
2 \\
1\end{array}$ & $\begin{array}{c}4.0 \\
24.0 \\
20.0 \\
20.0 \\
8.0 \\
12.0 \\
8.0 \\
4.0\end{array}$ \\
\hline $\begin{array}{l}\text { Lifetime risk of any siblings } n=43 \\
0 \\
1 \\
2 \\
3 \\
4 \\
5 \\
6 \\
8 \\
9\end{array}$ & $\begin{array}{l}17 \\
5 \\
5 \\
4 \\
1 \\
8 \\
1 \\
1 \\
1\end{array}$ & $\begin{array}{c}39.5 \\
11.6 \\
11.6 \\
9.3 \\
2.3 \\
18.6 \\
2.3 \\
2.3 \\
2.3\end{array}$ \\
\hline $\begin{array}{l}\text { Lifetime risk of any of parents } n=37 \\
0 \\
1 \\
2 \\
3 \\
4 \\
5 \\
6 \\
9\end{array}$ & $\begin{array}{c}18 \\
5 \\
5 \\
2 \\
2 \\
2 \\
1 \\
2\end{array}$ & $\begin{array}{c}48.6 \\
13.5 \\
13.5 \\
5.4 \\
5.4 \\
5.4 \\
2.7 \\
5.4\end{array}$ \\
\hline
\end{tabular}

More participants (75.6\%) had concerns about their families developing cancer and they identified such as not wanting their relatives to develop cancer like them (67.6\%) and desiring that the relatives will know how cancer can be prevented (Table 3). To this effect, most of the participants (93.5\%, 91.3\% and 93.3\%) would like their relatives to have GC, discuss their risks with a specialist and undergo GT, respectively (Table 3).

GT for risk assessment was perceived by the participants to be beneficial Top three of their perceived benefits of cancer GCT were, cancer prevention (89.4\%), early detection of cancer (70.2\%), motivation for self-examination (61.7\%). The most mentioned barriers to GC and testing services were cost (80.9\%), accessing testing centres (55.3\%) and availability of test (38.9\%) (Table 4). 
Table 3. Participants' concerns about their relatives' risks of cancer.

\begin{tabular}{|c|c|c|}
\hline Concerns about relatives' cancer risk & Frequency & $\%$ \\
\hline $\begin{array}{l}\text { Do you have concern about other relatives getting cancer } n=45 \\
\text { Yes } \\
\text { No }\end{array}$ & $\begin{array}{l}34 \\
11\end{array}$ & $\begin{array}{l}75.6 \\
24.4\end{array}$ \\
\hline $\begin{array}{l}\text { Concerns } n=34 \\
\text { I don't want them to develop cancer } \\
\text { I will like them to know that cancer can be prevented }\end{array}$ & $\begin{array}{l}23 \\
11\end{array}$ & $\begin{array}{l}67.6 \\
32.4\end{array}$ \\
\hline $\begin{array}{l}\text { Will you like for your relative to have GC? } n=46 \\
\text { Yes } \\
\text { No }\end{array}$ & $\begin{array}{c}43 \\
3 \\
\end{array}$ & $\begin{array}{c}93.5 \\
6.5 \\
\end{array}$ \\
\hline $\begin{array}{l}\text { Will you like your relative to discuss their risks with a specialist } n=46 \\
\text { Yes } \\
\text { No }\end{array}$ & $\begin{array}{c}42 \\
4 \\
\end{array}$ & $\begin{array}{l}91.3 \\
68.7 \\
\end{array}$ \\
\hline $\begin{array}{l}\text { Will you like your relatives to have GT } n=45 \\
\text { Yes } \\
\text { No }\end{array}$ & $\begin{array}{c}42 \\
3\end{array}$ & $\begin{array}{c}93.3 \\
6.7\end{array}$ \\
\hline
\end{tabular}

Table 4. Participants' perceived benefits and barriers of GT N $=47$.

\begin{tabular}{|c|c|c|}
\hline Perceived benefits & Frequency & $\%$ \\
\hline Motivate self-exam & 29 & 61.7 \\
\hline Helps family and children & 25 & 53.2 \\
\hline Reduces concern about cancer & 24 & 51.1 \\
\hline Reduces uncertainty & 20 & 42.5 \\
\hline Provides sense of personal control & 22 & 46.8 \\
\hline Helps plan the future & 27 & 57.4 \\
\hline Helps make important life decisions & 24 & 51.1 \\
\hline Helps with cancer prevention & 42 & 89.4 \\
\hline Early detection of BC & 33 & 70.2 \\
\hline \multicolumn{3}{|l|}{ Perceived barriers } \\
\hline Cultural perception & 11 & 23.4 \\
\hline Cost & 38 & 80.9 \\
\hline Access to the testing centre & 26 & 55.3 \\
\hline Availability of test & 18 & 38.3 \\
\hline Anticipated worry about offspring/relative if result is positive & 13 & 27.7 \\
\hline Anticipated personal emotion if result is positive & 18 & 38.3 \\
\hline Worry that other would find out & 12 & 25.5 \\
\hline Time & 7 & 14.9 \\
\hline Not wanting blood taken & 9 & 19.1 \\
\hline Lack of interest & 9 & 19.1 \\
\hline Worry about increased risk & 10 & 21.3 \\
\hline Worry about discomfort & 7 & 14.9 \\
\hline
\end{tabular}


All the participants planned to disclose and discuss their test results with their relatives who were mostly children (Daughters - 72.3\%, sons - 68.1\%) and siblings (sisters - 74.5\%, brothers 55.3\%) as shown in Table 5. As all the participants tested for genetic mutations, the result showed about $9.0 \%$ pathologic gene mutation which were in BRCA 1, BRCA 2 and ATM, negative result showing no mutations were $34.0 \%$ while more than half, $57.0 \%$ turned out to be variance of uncertain significance (VUS) (Figure 1). Details of the mutations are as follows: BRCA 1 variant c.5095C>T (p.Arg1699Trp) alternate names, g.41215948G>A, BIC: R1699W; BRCA 2 c.7900delA (p.Met2634Trpfs*14) alternate names, g.32936754delA, BIC: 8128delA; ATM variant c.1066-2A>T, alternate name, g.108119658A>T, ATM variant c.72+1G>A alternate name, g.108098424G>A. All mutations are of heterozygous.

Table 5. Relatives that participants would discuss result of GT with.

\begin{tabular}{|c|c|c|c|}
\hline \multicolumn{2}{|c|}{ Relatives to discuss result with } & Frequency & $\%$ \\
\hline \multicolumn{2}{|l|}{ Father } & 7 & 14.9 \\
\hline \multicolumn{2}{|l|}{ Mother } & 17 & 36.2 \\
\hline \multicolumn{2}{|c|}{ Brother(s) } & 26 & 55.3 \\
\hline \multicolumn{2}{|l|}{ Sister(s) } & 35 & 74.5 \\
\hline \multicolumn{2}{|c|}{ Daughter(s) } & 34 & 72.3 \\
\hline \multicolumn{2}{|l|}{ Son(s) } & 32 & 68.1 \\
\hline \multicolumn{2}{|l|}{ Spouse } & 18 & 38.3 \\
\hline \multirow[t]{5}{*}{ Others } & Step parents & 1 & 2.1 \\
\hline & Aunts & 8 & 17.0 \\
\hline & Uncles & 2 & 4.3 \\
\hline & Cousin(s) & 3 & 6.4 \\
\hline & Daughters-in-law & 1 & 2.1 \\
\hline
\end{tabular}

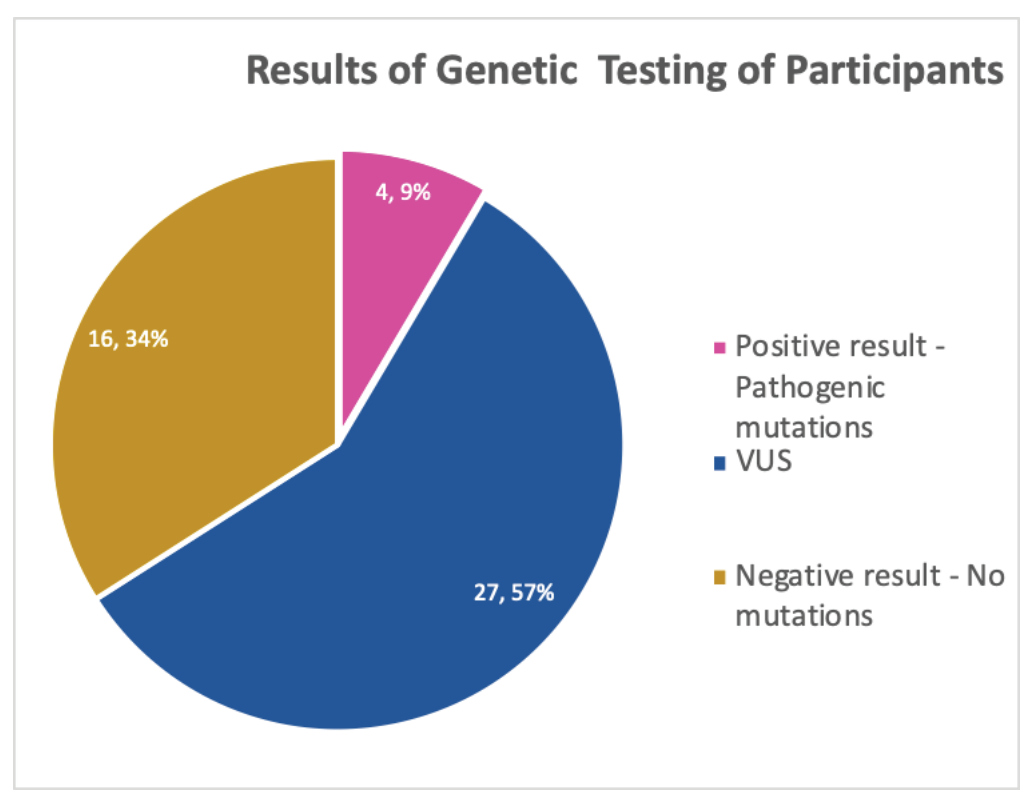

Figure 1. Results of GT undergone by the participants. 


\section{Discussion}

This study set out to explore the feasibility of an integrated CGC and testing in the care of individuals with cancers and their hereditary cancer at-risk relatives in $\mathrm{UCH}$, Nigeria. With the advent of more targeted and personalised approaches to cancer prevention and treatment, it has become imperative to understand the genetic basis of BC and gynaecological cancer such as OC and endometrial cancer. This is vital in providing patients with the needed effective preventive and/or management strategies towards improvement of outcomes. The causes of hereditary susceptibility to some women cancers have been documented to include hereditary cancer susceptibility genes, BRCA1 or BRCA2, associated with HBOC syndrome [22, 23], DNA mismatch repair genes, MLH1, MSH2, MSH6, or PMS2, in Lynch/Hereditary NonPolyposis Colorectal Cancer in endometrial, colorectal and OC [24, 25], Cowden syndrome in endometrial and BC [26, 27] and Li-Fraumeni syndrome in BC $[28,29]$. In this study, the patients' personal and relatives' perceived lifetime cancer risk was explored. The perceived personal risk of developing cancer of $17.2 \%$ is a pointer to the fact that the belief system still plays a role in the aetiology of the disease as cancer is generally perceived as a taboo among the people of African descent [30, 31]. This further shows a gap that needs to be filled by providing appropriate cancer genetic risk assessment education and cancer care practice in this era of personalised care. However, 63\% concerns the women communicated in the study about their relatives developing cancer is an indication for their ardent need for interventions in the area of CGC and service provision. This has also been shown in studies that positive perceptions of the public towards GT and its beneficial function in the healthcare as a factor in its uptake [32, 33]. This understanding of patients' perceived risk is salient to the establishment of cancer genetic risk assessment and management services as the risk of a second primary BC in BRCA 1 or 2 mutation carriers, particularly those diagnosed with BC at a younger age, is much higher (upwards of 50\%) than in non-carriers [34]. Also, with this knowledge, it is now paramount to identify women who carry mutations which can lead to the utilisation of the targeted medical advances in prevention, early detection and treatment $[35,36]$.

With the evidence that $5 \%-10 \%$ of BCs and $10 \%-15 \%$ of OCs are hereditary [37], the result of gene testing from this pilot study is not implausible. Moreover, up to $16 \%$ germline mutations have been reported in the Nigerian women with BC $[9,38]$. The authors believe that with the concerns of the patients about their relatives; possibility of getting cancer, the pooling of multiple generations with $\mathrm{BC}$, OC and other related cancers is possible. Efforts at cancer prevention and early detection have of recent been expanded towards pre-cancer/presymptomatic interventions [36]. These can be tailored to individual care given to women at increased risk for hereditary breast and gynaecological cancers.

A positive inclination in the patients' perceptions on the benefits of cancer genetic assessment services especially to their relatives was also noted. Studies found that members of families with identified BRCA 1 and 2 mutations were more likely to have GT when the genetic test results are shared $[39,40]$. In these families, cancer-specific distress and worry play a significant role in the choice to test for BRCA1 mutations as does a greater perceived risk of being a mutation carrier and of developing $B C$ or OC, and the perception that the advantages of BRCA testing outweigh the disadvantages [41]. The family serves as a vital communication nexus for information exchange [42] and may be an avenue for sharing information on cancer risk and prevention strategies. The intention to disclose and discuss the genetic test result to close relatives such as siblings and children is an indication of the assertion in other studies [40, 42].

Cancer risk assessment and associated GT are essential services in cancer risk prevention and are therefore important to be integrated to cancer care. This is, therefore, a right step in the right direction as the findings indicate its feasibility. This is crucial for a greater degree of personalised and yet comprehensive cancer care including GT for cancer risk assessment programme in Nigeria.

\section{Limitation of the study}

There is need for more data on a larger population for increased level of generalisation. Color Genomics ${ }^{\circledR}$ is the only laboratory engaged in this study which although have variants tested for African American population, is being engaged for the first time in the Nigerian population.

However, multi gene panels including Color Genomics ${ }^{\circledR} 30$ gene panel have been used extensively among African Americans. This advancement in sequencing panels for hereditary BC, OC and prostate cancer has shown that people of African descent tend to have more rare multiple variants and VUS than Caucasians $[43,44]$. Also, Color Genomics ${ }^{\circledR} 30$ gene panel has been used among Africans in Uganda and Cameroon [7]; therefore, this study relies on the result to provide population relevant data. 


\section{Conclusion}

Cancer GC and testing are perceived by patients in this study as beneficial for providing risk assessment for personalised patient care, early detection and prevention in women with high BC's and gynaecological cancers' risk. These results are important as GC and testing are expected to be offered to newly diagnosed BC, OC and endometrial cancer patients with increasing frequency in order to inform these women and their relatives about the possibility of a familial/hereditary nature of their disease to influence both their treatment and prevention for their family members. Proper education of the patients and their relatives on cancer genetic risk management will facilitate the required attention for maximal utilisation of cancer genetic services.

\section{Authors' disclosures of potential conflicts of interest}

Olufunmilayo I Olopade is an equity stock holder of CancerlQ. The other authors declare no conflicts of interest.

\section{Funding declaration}

This project was supported by National Institutes of Health grants from Susan G. Komen for the Cure (OIO) and Breast Cancer Research Foundation (OIO) the Color Genomics ${ }^{\circledR}$ Foundation.

\section{Reference}

1. Rahner N and Steinke V (2008) Hereditary cancer syndromes Dtsch Arztebl Int 105(41) 706-714 https://doi.org/10.3238/arztebl.2008.0706

2. Tsaousi GN, Papadopoulou E, and Apessos A, et al (2019) Analysis of hereditary cancer syndromes by using a panel of genes: novel and multiple pathogenic mutations BMC Cancer 19535 https://doi.org/10.1186/s12885-019-5756-4

3. Somasundaram K (2010) BRCA1 and BRCA1 genes and inherited breast and/or ovarian cancer: benefits of genetic testing Indian J Surg Oncol 1(3) 245-249 https://doi.org/10.1007/s13193-011-0049-7 PMID: 22693372 PMCID: 3244237

4. Rosenthal E, Moyes K, and Arnell C, et al (2015) Incidence of BRCA1 and BRCA2 non-founder mutations in patients of Ashkenazi Jewish ancestry Breast Cancer Res Treat 149(1) 223-227 https://doi.org/10.1007/s10549-014-3218-x

5. Palmer JR, Chunling Hu, and Hart S, et al (2012) Recurrent BRCA1 and BRCA2 mutations in breast cancer patients of African ancestry Breast Cancer Res Treat 134(2) 889-894 https://doi.org/10.1007/s10549-012-2136-z

6. Cherbal F, Bakour R, and Adane S, et al (2010) BRCA1 and BRCA2 germline mutations screening in Algerian breast/ovarian cancer families Dis Markers 28(6) 377-384 https://doi.org/10.1155/2010/585278 PMID: 20683152 PMCID: 3833328

7. Adedokun B, Zheng Y, and Ndom P, et al (2019) Prevalence of inherited mutations in breast cancer predisposition genes among Uganda and Cameroon women Cancer Epidemiol Biomarkers Prev 29(2) 359-367 https://doi.org/10.1158/1055-9965.EPI-19-0506 PMID: 31871109 PMCID: 7007381

8. Zhang J, Fackenthal J, and King MC, et al (2015) Inherited predisposition to breast cancer among African American women breast cancer Res Treat 149(1) 31-9 https://doi.org/10.1007/s10549-014-3195-0

9. Zheng Y, Walsh T, and Gulsuner S, et al (2018) Inherited breast cancer in Nigerian women J Clin Oncol 36(28) 2820-2825 https://doi. org/10.1200/JCO.2018.78.3977 PMID: 30130155 PMCID: $\underline{6161833}$ 
10. Torre LA, Trabert B, and DeSantis CE, et al (2018) Ovarian cancer statistics 2018 CA Cancer J Clin 68(4) 284-296 https://doi.org/10.3322/ caac.21456 PMID: 29809280 PMCID: 6621554

11. Bray F, Ferlay J, and Soerjomataram I, et al (2018) Global cancer statistics 2018: GLOBOCAN estimates of incidence and mortality worldwide for 36 cancers in 185 countries CA Cancer J Clin 68(6) 394-424 https://doi.org/10.3322/caac.21492 PMID: 30207593

12. Torre LA, Islami F, and Siegel RL, et al (2017) Global cancer in women: burden and trends Cancer Epidemiol Biomarkers Prev 26(4) 444457 https://doi.org/10.1158/1055-9965.EPI-16-0858 PMID: 28223433

13. Rivera-Franco MM, and Leon-Rodriguez E (2018) Delays in breast cancer detection and treatment in developing countries Breast Cancer Basic Clin Res 12 1178223417752677 https://doi.org/10.1177/1178223417752677

14. Nelson HD, Pappas M, and Zakher B, et al (2014) Risk assessment, genetic counseling, and genetic testing for BRCA-related cancer in women: a systematic review to update the U.S. preventive services task force recommendation Ann Intern Med 160(4) 255-266 https:// doi.org/10.7326/M13-1684

15. Chan IS and Ginsburg GS (2011) Personalized medicine: progress and promise. Annu Rev Genomics Hum Genet 12 217-244 https://doi. org/10.1146/annurev-genom-082410-101446 PMID: 21721939

16. Lopez V (2018) Genetic testing: do cancer care nurses have a role? Asia-Pac J Oncol Nurs 5(4) 391-393 https://doi.org/10.4103/apjon. apjon_23_18 PMID: 30271821 PMCID: $\underline{6103194}$

17. Battista RN, Blancquaert I, and Laberge AM, et al (2012) Genetics in health care: an overview of current and emerging models Public Health Genomics 15 34-45 https://doi.org/10.1159/000328846

18. Adejumo PO, Aniagwu TI, and Oluwatosin OA, et al (2018) Knowledge of genetic counselling among patients with breast cancer and their relatives at a Nigerian teaching hospital J Glob Oncol 4 1-8 PMID: 30084716 PMCID: 6223535

19. Cohen SA, Bradbury A, and Henderson V, et al (2019) Genetic counseling and testing in a community setting: quality, access, and efficiency Am Soc Clin Oncol Educ Book 39 e34-e44 https://doi.org/10.1200/EDBK_238937 PMID: 31099680

20. MacDonald DJ, Blazer KR, and Weitzel JN (2010) Extending comprehensive cancer center expertise in clinical cancer genetics and genomics to diverse communities: the power of partnership J Natl Compr Cancer Netw 8(5) 615-624 https://doi.org/10.6004/ jnccn.2010.0046

21. Druker H, Zelley K, and McGee RB, et al (2017) Genetic counselor recommendations for cancer predisposition evaluation and surveillance in the pediatric oncology patient Clin Cancer Res 23(13) e91-e97 https://doi.org/10.1158/1078-0432.CCR-17-0834 PMID: 28674117

22. Kobayashi H, Ohno S, and Sasaki Y, et al (2013) Hereditary breast and ovarian cancer susceptibility genes Oncolo Rep 30 1019-1029 https://doi.org/10.3892/or.2013.2541

23. Saam J, Moyes K, and Landon M, et al (2015) Hereditary cancer-associated mutations in women diagnosed with two primary cancers: an opportunity to identify hereditary cancer syndromes after the first cancer diagnosis Oncol 88 226-233 https://doi. org/10.1159/000368836

24. Banno K, Kisu I, and Yanokura M, et al (2013) Hereditary endometrial cancer: Lynch syndrome Curr Obstet Gynecol Rep 2 11-18 https:// doi.org/10.1007/s13669-012-0029-0

25. Nakamura K, Banno K, and Yanokura M, et al (2014) Features of ovarian cancer in Lynch syndrome Mol Clin Oncol 2 909-916 https:// doi.org/10.3892/mco.2014.397 PMID: 25279173 PMCID: 4179837

26. Gammon A, Jasperson K, and Champine M (2016) Genetic basis of Cowden syndrome and its implications for clinical practice and risk management Appl Clin Genet 9 83-92 https://doi.org/10.2147/TACG.S41947 PMID: 27471403 PMCID: 4948690 
27. Minamiguchi K, Takahama J, and Uchiyama T, et al (2018) Uterine endometrial carcinoma with DNA mismatch repair deficiency: magnetic resonance imaging findings and clinical features Jpn J Radiol 36 429-436 https://doi.org/10.1007/s11604-018-0741-4 PMID: $\underline{29728922}$

28. Neto N and Cunha TM (2015) Do hereditary syndrome-related gynecologic cancers have any specific features? Insights Imaging 6(5) 545-552 https://doi.org/10.1007/s13244-015-0425-x PMID: 26337050 PMCID: 4569599

29. Penkert J, Schmidt G, and Hofmann W, et al (2018) Breast cancer patients suggestive of Li-Fraumeni syndrome: mutational spectrum, candidate genes, and unexplained heredity Breast Cancer Res 2087 https://doi.org/10.1186/s13058-018-1011-1 PMID: 30086788 PMCID: $\underline{6081832}$

30. Ehiwe E, McGee P, and Thomson K, et al (2013) How black West African migrants perceive cancer Divers Equal Health Care 10 115-21

31. Tetteh DA and Faulkner SL (2016) Sociocultural factors and breast cancer in sub-Saharan Africa: implications for diagnosis and management Women's health (Lond) 12(1) 147-156 https://doi.org/10.2217/whe.15.76

32. Haga SB, Barry WT, and Mills R, et al (2013) Public knowledge of and attitudes toward genetics and genetic testing Genet Test Mol Biomarkers 17(4) 327-35 https://doi.org/10.1089/gtmb.2012.0350 PMID: 23406207 PMCID: 3609633

33. Etchegar H (2014) Public attitudes toward genetic risk testing and its role in healthcare Personalized Med 11(5) 509-22 https://doi. org/10.2217/pme.14.35

34. Pal T and Vadaparampil ST (2012) Genetic risk assessments in individuals at high risk for inherited breast cancer in the breast oncology care setting Cancer Control 19(4) 255-266 https://doi.org/10.1177/107327481201900402 PMID: 23037493 PMCID: 4009502

35. Olopade OI, Grushko T, and Nanda R, et al (2008) Advances in breast cancer: pathways to personalized medicine Clin Cancer Res 14(24) 7988-7999 https://doi.org/10.1158/1078-0432.CCR-08-1211 PMID: 19088015 PMCID: 4535810

36. Loomans-Kropp HA and Umar A (2019) Cancer prevention and screening: the next step in the era of precision medicine Npj Precis Oncol 33 https://doi.org/10.1038/s41698-018-0075-9 PMID: 30701196 PMCID: 6349901

37. Lynch JA, and Berse VVB (2015) Genetic tests to identify risk for breast cancer Semin Oncol Nurs 31(2) 100-107 https://doi.org/10.1016/j. soncn.2015.02.007 PMID: 25951739 PMCID: 4998965

38. Fackenthal JD, Zhang J, and Zhang B, et al (2012) High prevalence of BRCA1 and BRCA2 mutations in unselected Nigerian breast cancer patients Int J Cancer 131(5) 1114-1123 https://doi.org/10.1002/ijc.27326

39. Biesecker BB, Ishibe N, and Hadley DW, et al (2000) Psychosocial factors predicting BRCA1/BRCA2 testing decisions in members of hereditary breast and ovarian cancer families Am J Med Genet 93(4) 257-63 https://doi.org/10.1002/10968628(20000814)93:4<257::AID-AJMG1>3.0.CO;2-8 PMID: 10946349

40. Vadaparampil ST, Malo T, and de la Cruz C, et al (2012) Do breast cancer patients tested in the oncology care setting share BRCA mutation results with family members and health care providers? J Cancer Epidemiol 201210 https://doi.org/10.1155/2012/498062

41. Schlich-Bakker K, ten Kroode $\mathrm{H}$, and Wárlám-Rodenhuis $\mathrm{C}$, et al (2007) Barriers to participating in genetic counseling and BRCA testing during primary treatment for breast cancer Genet Med 9 766-777 https://doi.org/10.1097/GIM.0b013e318159a318 PMID: 18007146

42. Chopra I and Kelly KM (2017) Cancer risk information sharing: the experience of individuals receiving genetic counseling for BRCA1/2 mutations J Health Commun 22(2) 143-152 https://doi.org/10.1080/10810730.2016.1258743 PMID: 28112991 PMCID: 5586537

43. Neben CL, Zimmer AD, and Stedden W, et al (2019) Multi-Gene panel testing of 23,179 individuals for hereditary cancer risk identifies pathogenic variant carriers missed by current genetic testing guidelines J Mol Diagn 21(4) 646-657 https://doi.org/10.1016/j. jmoldx.2019.03.001 PMID: $\underline{31201024}$

44. Bishop MR, Omeler-Fenaud SM, and Huskey ALW, et al (2020) Gene panel screening for insight towards breast cancer susceptibility in different ethnicities PLoS One 15(8) e0238295 https://doi.org/10.1371/journal.pone.0238295 PMID: 32866190 PMCID: 7458311 